\title{
Analysis of the Challenges and Technical Solutions for Revitalization of Traditional Buildings in Hot and Humid Climate (Case Study: Anthropology Museum of Local Residents in Kish Island)
}

\author{
Soroush Nikeghbali ${ }^{a^{*}}$, Ali Damavandi ${ }^{b}$ \\ ${ }^{a}$ PhD in Urban Design, Oxford Brookes University, Oxford, UK. \\ ${ }^{b}$ Department of Mechanical Engineering, Faculty of Engineering, Central Tehran Branch, Islamic Azad University, Tehran, Iran . \\ Received 10 March 2018; Accepted 27 September 2018
}

\begin{abstract}
In every nation ancient buildings are rich sources for inspiration from local traditional architecture. Manu of such buildings still have potentials for conservation and renovation. This article reviews the issue of revitalization of old traditional buildings in south part of Iran with hot and humid climate. The key technical challenges of revitalization and renovation of such buildings were explored via literature review. Then, the technical solution for such challenges were identified via cases study analysis. In order to reach comprehensive and practical solutions, tree key field of built environment studies which are architecture, structure and infrastructure design were explored together. The case study for this research was the project of revitalization of a traditional building into "Anthropology Museum of Local Residents" in Kish Island. The analysis and case study showed that most of the technical challenges for revitalization of such buildings are resolvable via simple solutions. Based on this, economic and socio-cultural supports of local authorities and planning departments are necessary in order to make such revitalization projects more feasible.
\end{abstract}

Keywords: Revitalization; Traditional Architecture; Hot And Humid Climate; Technical Challenges; Structure; Infrastructure; Kish Island.

\section{Introduction}

This study is aimed in investigating the main challenges in field of revitalization of worn out textures and old buildings in hot and humid regions of Iran. The main objective of this study is to show that what are the key problems with the executive agents of revitalization projects of historical textures in this region in general? Knowing such factors can help scholars have more comprehensive attitude towards revitalization projects to have better plans to meet the upcoming difficulties. Moreover, such study helps providing opportunity for further studies and finding better solutions to meet the executive barriers to revitalization of worn out textures.

\section{The Goals of Revitalization}

The issue of revitalization of worn out textures and old buildings has been always one of the most important branches in field of construction. According to the value of these textures, revitalization of them can have various goals. One of the most important goals could be providing opportunity of better life for local residents of these worn out textures. As strong social integration has been created in these textures over the time, protection and revitalization of physical form of city can help this rooted social system to continue living.

* Corresponding author: soroushnikeghbali@yahoo.com

dol http://dx.doi.org/10.28991/cej-03091173

$>$ This is an open access article under the CC-BY license (https://creativecommons.org/licenses/by/4.0/).

(C) Authors retain all copyrights. 
Moreover, worn out textures can attract tourists, especially in country like Iran with traditional and local richness and antiquity. Development of tourism can help economic prosperity whether in micro and local scale or macro and national scale. In general, the revitalized buildings providing tourism services can provide opportunity for revitalization of adjacent buildings and employment for local residents. The process can as a result lead to economic and social renovation of the region and can pave the way for physical revitalization of other buildings and creating other constructional functions to give service to tourists.

On the other hand, revitalization of worn out buildings with architectural richness can protect scientific and artistic heritage of ancient architects. At the current world with modern buildings, the old buildings can be a benchmark for localization of architecture and creation of special identity for different regions of Iran. Through protecting such old buildings, the opportunity can be created for the future generations to study the architectural principles and solutions of antecedents to find appropriate solutions for the today's construction [1].

\section{Revitalization in Hot and Humid Climate}

This study is focused on revitalization of worn out textures in south of Iran with hot and humid climate. Wide range of Iran along the Oman Sea and Persian Gulf has such climate. People of 4 southern provinces of Iran, especially in coastal area, live under such climatic condition and it is difficult to live there in hot seasons of the year. Such climate can cause severe erosion of buildings of this region compared to other regions of Iran and can highlight the issue of revitalization of worn out textures [2].

At the old cities and traditional textures of this zone, there are many old buildings with the value of protection and revitalization. The process of revitalization of old buildings has been also developed over the years. Particularly, old buildings of the region can be valuable benchmark for the architectures and construction executive management. The old buildings are built in such way that they can provide welfare and comfort of residents in the hard climate of the region using simple and natural solutions and with least energy consumption [3-5]. As providing welfare of residents in this zone is more difficult than other climates in Iran, understanding the principles of construction in these buildings can help finding economic solutions for the today's constructions.

Along with historical value of these worn out textures, hot and humid climate of the zone has accelerated the erosion of these textures. Accordingly, number of revitalized buildings is almost fewer than other climates. This shows the importance of revitalization of buildings of this zone. Still many old neighbourhoods of southern zone are crowded and these regions have protected their social texture. More efforts should be taken to preserve physical integration of these regions to protect the rich construction heritage of these regions.

\section{Technical and Executive Approach to Study Revitalization}

The main focus of this study is on issues, which can be challenging during the practical process of revitalization from designation to implementation and utilization of building. In fact, this study tends to show the key issues created for experts in field of construction. Hence, this study tends to provide a codified and comprehensive thinking framework for the executors of revitalization projects to make plans for main challenges of these projects.

This study has applied two main methods of library studies and case study of old and revitalized buildings. Over the years, lots of valuable articles have been presented in field of value of traditional textures and case study of these textures. There is still long way for preservation and scientific registration of the historical heritage. However, this study tends to look at the issue of worn out buildings in different way and consider useful issue in practical and executive field of revitalization of these buildings. Hence, this study has considered not only architectural issues of these buildings, but also two other main fields of construction fields including structure and infrastructures. In any kind of construction project, 3 issues of architecture, structure and infrastructure should be considered alongside, so that a comprehensive executive solution is provided ultimately. As a result, this study has integrated the 3 issues of construction sciences to have focus on thematic interactions of these fields in field of revitalization of traditional buildings. As a result, the results of this research could be practical and valuable. In fact, this study clears the executive dimensions of revitalization project by means of 3 main aspects of construction sciences and takes effort to provide a framework to identify main barriers to revitalization and find solutions for them.

\section{Methodology}

This study has been conducted in two main steps. In first step, theoretical framework of the research is provided using library investigations. In second step, a case study is done on old building in hot and humid climate based on the theoretical framework. Hence, the theoretical framework of research has specified the underlying issues in field of technical challenges for revitalization of traditional buildings. In second step, using case study and field study, practical solutions are used to solve these challenges in a real-time revitalization project. Field study includes investigation of building in terms of physical form and architecture, landscaping, implementation, reinforcement, adding modern 
infrastructure systems and changes compared to last time through studying previous and present status of the building.

\section{Theoretical Framework of Research}

In field of finding relevant issues of revitalization of old buildings from technical and executive perspective, library studies are conducted with such objective. These studies are focused on 3 main fields of architecture, structure and infrastructure of old buildings. The main objective of these investigations was finding the most important technical and executive issues in the 3 mentioned fields and determining the most important challenges for executive managers of reconstruction projects. Moreover, the study has attempted to investigate the technical issues relevant to buildings built using old materials and architecture and under hard climatic conditions of hot and humid areas.

Accordingly, in field of architectural design, the most underlying issues considered are associated with preservation of overall form of spaces usually built under the said climates in form of central courtyard and residential rooms around the yard. In this field, some challenges area also existed to protect the structure of central courtyard in new reconstructions. This is because; for needs to wider spaces and due to the today's lifestyle and small size of families and need to smaller houses, the buildings of central courtyards can't sometimes meet needs of new residents [6]. Moreover, another underlying issue in field of architecture of buildings under this climate is the issue of preservation of semi-open spaces and creating air current for air conditioning [7]. Again due to change in today's lifestyle and more use of artificial air conditioners and coolers, the modern architecture of hot and humid areas has been conducted towards absolutely closed spaces, despite to the past times, which has led to change in form of architectural spaces. In field of structural issues, the most underlying issue is the issue of building subsidence because of traditional foundations and rapid erosion of load tolerating materials over the time. As erosion of building is severe and rapid in these regions, protection of buildings and consideration of structural issues is very important. Moreover, it has been observed that increased number of thatch layers in roof of these buildings has led to increased weight of ceiling and decreased safety of interior space.

In terms of infrastructural issues, one of the main challenges in these buildings is the issue of providing essential infrastructures and facilities of today's life. Issues such as adding water and wastewater piping and providing space and installation of today's infrastructure systems inside old buildings can be a serious challenge for executive managers of these projects.

According to the mentioned, Table 1 has presented the most underlying issues and challenges for revitalization of old buildings in hot and humid climate. The table has provided theoretical framework of research, through which the case study in analytical section of research can be investigated.

Table 1. Main technical challenges of revitalization based on library studies

\begin{tabular}{|c|c|c|c|c|}
\hline & Topic & Reference & Objective & Challenges \\
\hline \multirow{4}{*}{ 异: } & $\begin{array}{l}\text { 1. Courtyard in } \\
\text { Building }\end{array}$ & Ghobadi, 2014 [8] & $\begin{array}{l}\text { Preservation of form of central courtyard and } \\
\text { spatial position of courtyard }\end{array}$ & $\begin{array}{l}\text { Lack of space for building and need to extend the } \\
\text { space }\end{array}$ \\
\hline & $\begin{array}{l}\text { 2. Shading on Open } \\
\text { Spaces and Terrace }\end{array}$ & $\begin{array}{l}\text { Rashidian, } 2014 \text { [9] } \\
\text { Deljavan farshi, } 2013 \\
\text { [10] } \\
\text { Farhadian, } 2016[11]\end{array}$ & $\begin{array}{l}\text { Increase in interior and shaded spaces in } \\
\text { building } \\
\text { Placement of open spaces in such way that } \\
\text { they are shaded major part of daytime }\end{array}$ & $\begin{array}{l}\text { Preservation of shaded spaces and increasing such } \\
\text { spaces despite to lack of space inside the building }\end{array}$ \\
\hline & 3. Building Height & & $\begin{array}{l}\text { Protection of low height of building and } \\
\text { creating sense of openness of area }\end{array}$ & $\begin{array}{l}\text { Need to wider spaces } \\
\text { Low shading of these low-heighted spaces }\end{array}$ \\
\hline & 4. Building Façade & $\begin{array}{l}\text { Chitsazan, } 2013[12] \\
\text { Zanjani, } 2013[13] \\
\text { Ghobadian, } 1998[2]\end{array}$ & $\begin{array}{l}\text { Preservation of local materials and creating } \\
\text { thermal insulator }\end{array}$ & $\begin{array}{l}\text { Lack of skylight and window in old buildings and } \\
\text { contradiction with current needs } \\
\text { Using insulator and combining it to old material in } \\
\text { the building }\end{array}$ \\
\hline \multirow{4}{*}{ 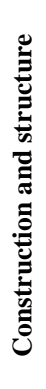 } & 1. Erosion & Kuravand, 2015 [14] & $\begin{array}{l}\text { Increased lifetime of building and materials } \\
\text { in hot and humid climate }\end{array}$ & $\begin{array}{l}\text { Continuous and long-time depreciation of old } \\
\text { materials of the building }\end{array}$ \\
\hline & 2. Earthquake & & $\begin{array}{l}\text { Safety of old building against earthquake and } \\
\text { seismic loads }\end{array}$ & $\begin{array}{l}\text { Lack of using modern materials and presence of } \\
\text { heavy materials in old building } \\
\text { Lack of resistant skeleton }\end{array}$ \\
\hline & $\begin{array}{l}\text { 3. Skeleton and } \\
\text { Materials }\end{array}$ & $\begin{array}{l}\text { Alipour, } 2015[15] \\
\text { Madi, } 2014 \text { [16] } \\
\text { Kuravand, } 2015 \text { [14] }\end{array}$ & $\begin{array}{l}\text { Using high quality materials and making } \\
\text { resistant skeleton for building }\end{array}$ & $\begin{array}{l}\text { Combining skeleton with current status of building } \\
\text { Lighting old thatch ceilings }\end{array}$ \\
\hline & $\begin{array}{l}\text { 4. Building } \\
\text { Subsidence }\end{array}$ & & $\begin{array}{l}\text { Protecting building against more subsidence } \\
\text { over the time }\end{array}$ & Retrofitting the soil in foundation of building \\
\hline
\end{tabular}




\begin{tabular}{|c|c|c|c|c|}
\hline \multirow{4}{*}{ 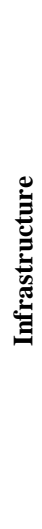 } & $\begin{array}{l}\text { 1. Achieving } \\
\text { Favourable Interior } \\
\text { Temperature }\end{array}$ & $\begin{array}{l}\text { Sayadzadeh, } 2015[17] \\
\text { Zanjani, } 2013[13] \\
\text { Jalili, } 2016[18]\end{array}$ & $\begin{array}{l}\text { Creating economic heating and cooling } \\
\text { system in the building }\end{array}$ & $\begin{array}{l}\text { Piping inside the walls of old buildings } \\
\text { Combining new system with natural old systems } \\
\text { Embedding systems in appropriate interior space }\end{array}$ \\
\hline & 2.Insulator & Jalili, 2016 [18] & Declining thermal waste of building & $\begin{array}{l}\text { Suitable pipe insulation } \\
\text { Floor and wall insulation } \\
\text { Insulation of thatch ceiling }\end{array}$ \\
\hline & $\begin{array}{l}\text { 3. Reducing Air } \\
\text { Humidity }\end{array}$ & Sayadzadeh, 2015 [17] & $\begin{array}{l}\text { Creating suitable set point of humidifier for } \\
\text { residents }\end{array}$ & $\begin{array}{l}\text { Combining suitable air conditioning system with old } \\
\text { building } \\
\text { Using suitable heating and cooling systems for these } \\
\text { climate and challenge of installing them inside the } \\
\text { building } \\
\text { Cost-effective infrastructures for these buildings }\end{array}$ \\
\hline & 4. Rust and Corrosion & & Renovation of rusted materials & Limited access to old rusted parts \\
\hline
\end{tabular}

\section{Introducing the Case Study: Anthropology Museum of Local Residents in Kish Island}

To complete analytical section of research, a case study is done on a building in hot and humid climate of Iran. Case study is the building of Anthropology Museum of Local Residents in Kish Island. The old building is located in northwest of Kish Island and in old neighborhood of Safin, Kish. The building has been a residential building belonged to a merchant before revitalization. The building has a complete form and has all essential factors and spaces of living in ancient times including two courtyards and rooms with different functions surrounded the yard. Same absolute form and providing all required traditional spaces can help providing more comprehensive analysis and results for this study.

The building includes two central courtyards, one used as indoor space and one used as outdoor space. Moreover, rooms and more private space are placed around the indoor courtyard and the public spaces are placed around the outdoor yard. Although the building has an antiquity about 200 years, it has provided good opportunity for revitalization and changing the use due to appropriate protection of the building. The building has been reconstructed over the years and has been used publically as Anthropology Museum of Local Residents in Kish Island.

In Safin district, Kish, there are many old buildings; although rare construction is done in this region and if construction is done, it is done using modern materials and technology and with destruction and change of traditional form of the building. However, buildings and rich urban texture of the region can provide opportunity to attract tourist and to preserve local architectural and artistic heritage of Kish if they are revitalized. The issue of revitalization, change in function of Anthropology Museum of Local Residents in Kish Island and changing in to applicable space can be an opportunity to study challenges and opportunities to revitalize other old buildings in this old district of Kish. In rest of article, through analyzing existing status of reconstructed building, technical solutions used to encounter revitalization challenges of these buildings are specified.

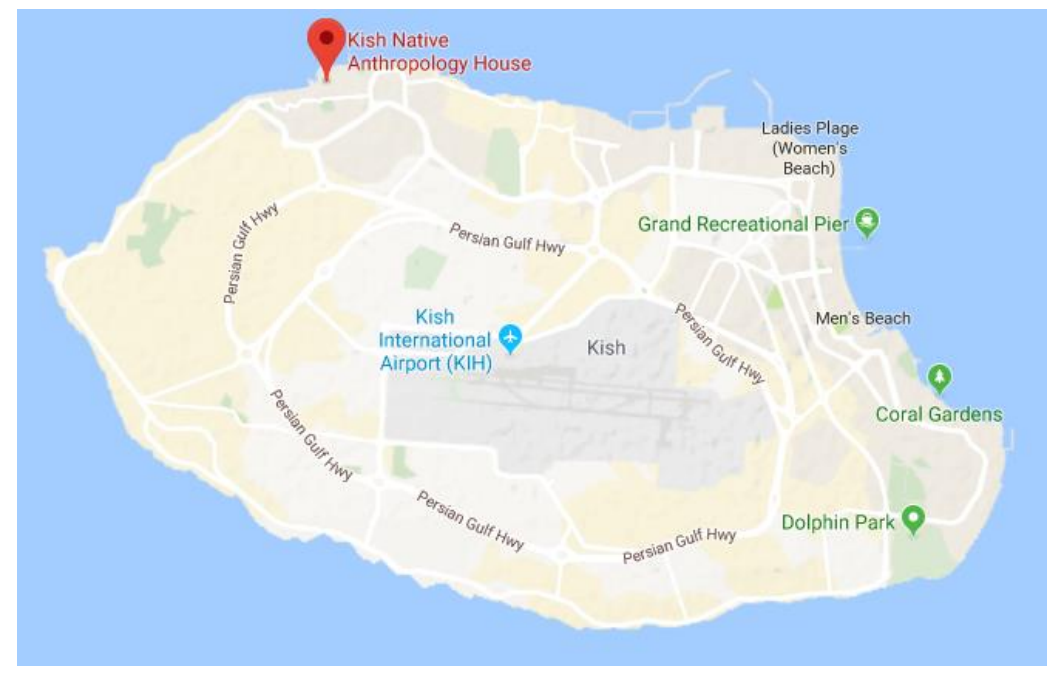

Figure 1. Anthropology Museum of Local Residents in Safin, Kish

\section{Analysis of Case Study (General Explanation, Architecture, Infrastructure and Structure)}

According to table 1 and theoretical framework, the case study is analyzed. Accordingly, through analysis of case study, the solutions applied for each mentioned challenge are identified. The solutions are again in 3 main fields of architectural design, structure and resistance of building and infrastructure. Table 2 presents the results of this analysis. 
Table 2. Solutions to solve the technical challenges of revitalization based on case study

\begin{tabular}{|c|c|c|}
\hline & Topic & Solutions in Kish Case Study \\
\hline \multirow{6}{*}{ 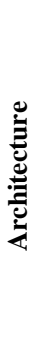 } & \multirow{2}{*}{ Courtyard in building } & Preservation of central courtyard in old form and increasing semi-open spaces (figure 2) \\
\hline & & Maximum use of central courtyard for sitting spaces due to new public function of building (figure 3 ) \\
\hline & $\begin{array}{l}\text { Shading on open spaces and } \\
\text { terrace }\end{array}$ & Using canopy in different parts of courtyard (figure 4) \\
\hline & \multirow{2}{*}{ Building height } & No change in 4-meter height of building \\
\hline & & Preserving physical form of building in old form and 1-storey form and using same spaces in the flat floor \\
\hline & Building façade & Using local materials and furniture like mat and thick rope to form courtyard and sitting spaces (figure 5) \\
\hline \multirow{6}{*}{ 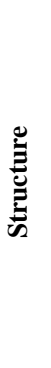 } & Earthquake & Using brace for courtyard walls and outdoor walls for more resistance (figure 6) \\
\hline & \multirow{2}{*}{ Skeleton and materials } & Using wood and local and natural materials for shading ceilings \\
\hline & & Using thick walls as insulator (figure 4 and 8 ) \\
\hline & Building subsidence & Protecting wooden frames of doors for resistance of openings (figure 7) \\
\hline & Achieving favourable interior & Using split to make inside spaces cool (figure 8) \\
\hline & temperature & Placement of condensers in less-observable corners of courtyard and under the shade of walls (figure 4) \\
\hline \multirow{3}{*}{ 葛 } & \multirow[t]{2}{*}{ Insulation } & $\begin{array}{l}\text { Protecting old materials like Sarouj (mortar) for inside and outside façade of building causing resistance } \\
\text { and relative insulation }\end{array}$ \\
\hline & & Protecting thick walls of building causing reduced thermal wastage \\
\hline & Reduced air humidity & Using platforms for rest spaces at the courtyard to reduce air humidity (figure 9) \\
\hline
\end{tabular}

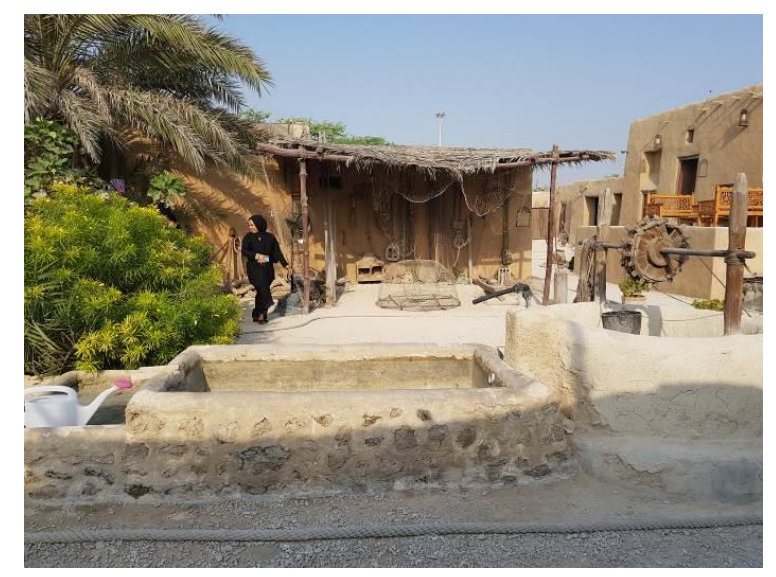

Figure 2. Protecting central courtyard and semi-open spaces

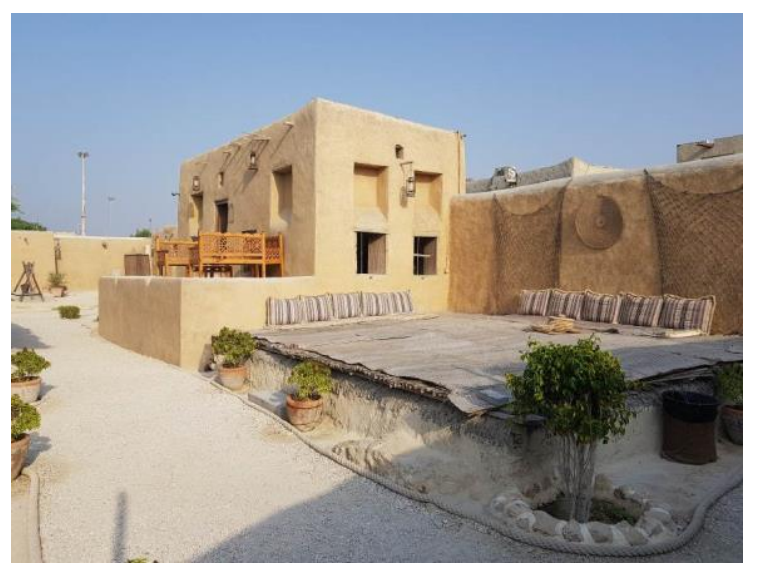

Figure 3. Using central courtyard for new public spaces for rest of visitors 


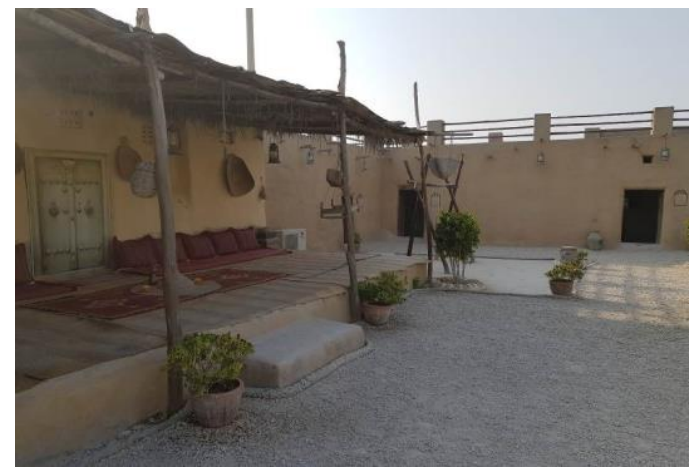

Figure 4. Using local materials to make shading space at the courtyard

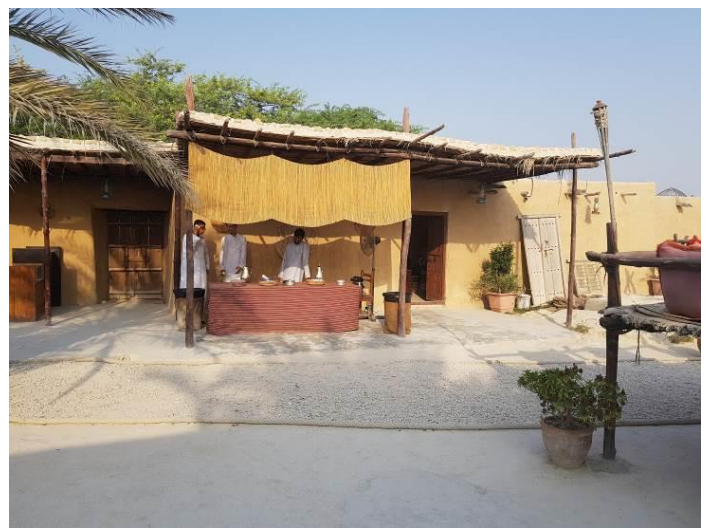

Figure 5. Using local and simple materials like wood mat and rope to form courtyard and create furniture

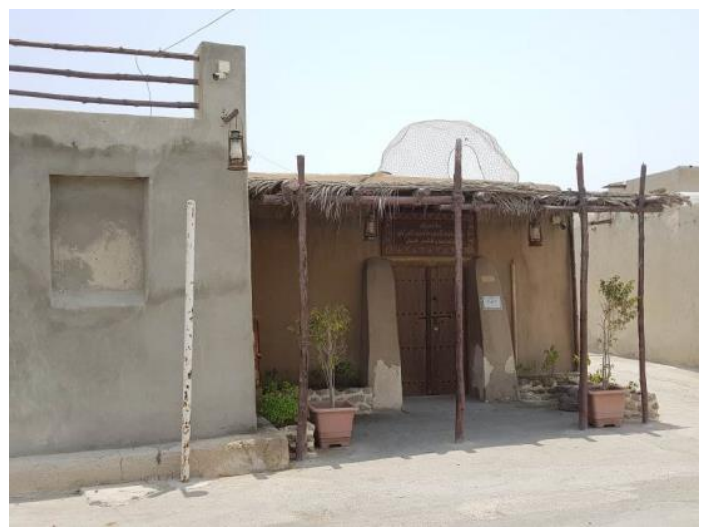

Figure 6. Using bracing in walls and wood in skeleton of canopies for relative resistance against earthquake

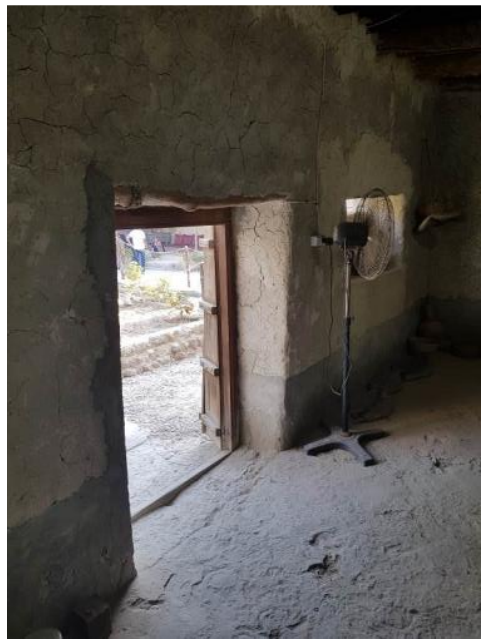

Figure 7. Using wooden frame of doors for resistance of walls, protecting thick walls with high thermal capacity causing suitable insulation of inside spaces 


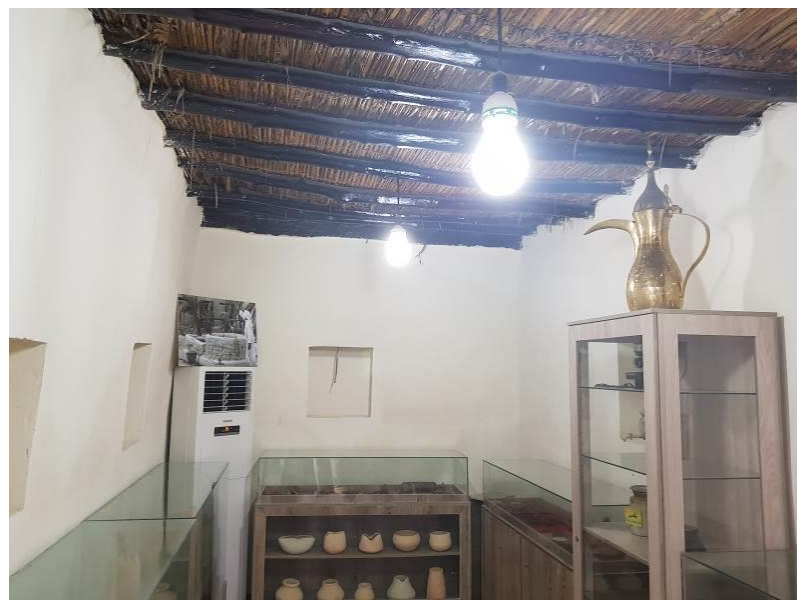

Figure 8. Using separate split systems to cool each space

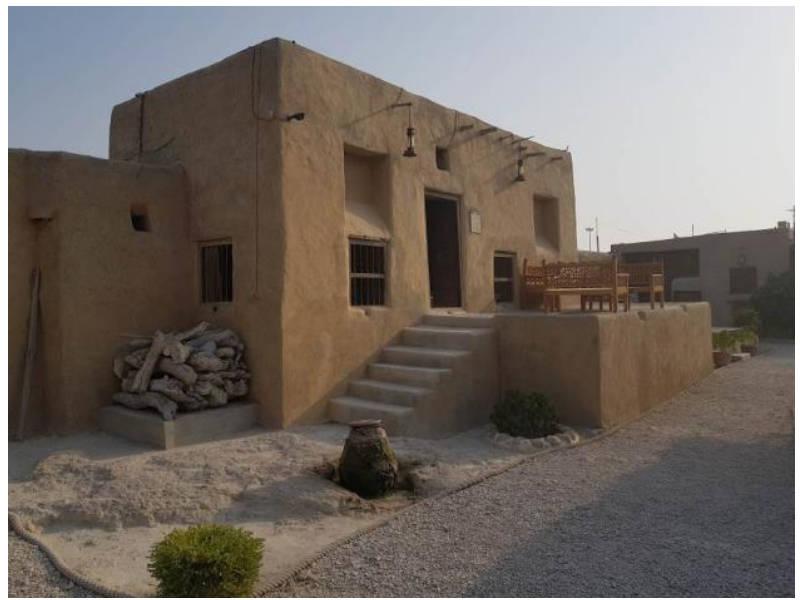

Figure 9. Using platform and different platform levels in several spaces to reduce the problems caused by ground humidity

\section{Conclusion}

Over the years, revitalization of old buildings has been replaced instead of destroying them and it is expected that the process can be developed in future. The case study and analysis in this research showed that many upcoming technical challenges for revitalization of old buildings can be solved. The case study in this research is residential building changing function to museum. Accordingly, the spaces have gained different uses. At the same time, with regard to same changes, it could be found that revitalization of such buildings is possible, along with preserving their residential use.

Benchmarking the revitalization projects and finding new solutions can help revitalization of more old buildings in future and preservation of their architecture and construction richness. In Safin Neighborhood in Kish, there are many buildings with the potential of revitalization and optimal use of them. Such situation is also existed in lots of traditional neighbourhoods of cities in south of Iran and such revitalization and renovation projects are being developed.

Although technical and executive challenges of revitalization projects are solvable and there are adequate solutions for them, there are still some challenges in macro scale preventing prosperity of these projects. Solving the problems can significantly help protection and revitalization of remained traditional buildings. In this field, one of the most underlying issues is culture. In this field, it could be observed that tendency of residents and even other people to preserve and revitalize old buildings are being increased. This issue is depended on value and importance of rich cultural and construction heritage in culture residents. Moreover, in economic terms, financial supports and allocation of budget by the government is needed to develop the revitalization projects. In the case study of Kish, revenue and profitability of such projects in Safin Neighborhood is depended on long-term investment, attracting tourist for the district and economic supports of the government. Moreover, in terms of urbanization, providing infrastructures like water piping, electricity, gas piping, road construction, public and service space construction, quality of streets, green spaces and sidewalks can make motivation in residents and investors out of the region in order to take a step towards revitalization of traditional buildings and monuments in such regions. 


\section{References}

[1] Alexander, Christopher. A pattern language: towns, buildings, construction. Oxford university press, (1977).

[2] Ghobadian, V. "The Climatic Investigation of the Traditional Iranian Buildings," Tehran University Press, Tehran, Iran, (1998).

[3] Kasmaei, M. "Climate and Architecture", Khak Publications, Isfahan, Iran, (2003).

[4] Moshiri, Sh. "Sustainable design based on hot and humid climate," City identity, 39-46. (2009).

[5] Watson, D. And Lebs, K. "Climate Design," University Press, Tehran, Iran, (2011).

[6] Madanipour, A. Sustainable Development, Urban Form, and Megacity Governance and Planning in Tehran, in: Sorensen, A. Okata, J (eds.) Megacities: Urban Form, Governance and Sustainability, (2010). London: Springer

[7] Razjuyan, M. "Comfort in the shelter of wind" Shahid Beheshti University, Tehran, Iran, (2007).

[8] Ghobadi Saki, A and Tabatabaei Melazi, F. And Sabernezhad, J. "The Pattern of Free Space in a Hot and Humid Climate with orientation of central courtyard", Proceedings of the 2nd International Congress on Structure, Architecture and Urban Development, Tehran, Iran, . (2014).

[9] Rashidian, N. And Khodadadi, N. "Recognition of the Sustainability Model in the Architecture of Traditional Houses of Iran's Hot and Humid Areas by Introducing an Example of Traditional Houses in these Areas," Proceedings of the First National Conference on Urbanism, Urban Management and Sustainable Development, Tehran, Iran, (2014).

[10] Deljavan Farshi, N. And Khodakarami, J. And Nasrollahi, N and Sarkardeh, F. "The effect of terrace on the amount of natural ventilation for optimal energy consumption in warm and humid climates", Proceedings of the Third International Conference on Modern Approaches to Energy Conservation, Tehran, Iran, (2013).

[11] Farhadian, M. "Climate Designing Solutions in the Hot and humid Region," Proceedings of the Second Annual Conference of Architecture, Urban Planning and Urban Management Research, Tehran, Iran, (2016).

[12] Chitsazan, R and Noori Mokarram, A. "The role of green building in hot and humid climate architecture, according to the principles of sustainable development," Proceedings of the first international conference and the 4th National Conference on Urban Development, Tehran, Iran, (2013).

[13] Zanjani Mokhtar, N and Fotohi, F and Mosharraf, H. "Appropriate Solutions for Reducing the Energy Consumption Level of Residential Buildings in a Hot and humid Climate," Proceedings of the First National Conference on Architecture, Restoration, Urbanism and Sustainable Environment, Tehran, Iran (2013).

[14] Kuravand Bordpareh, S and Rahanjam, A, Gholipour Noroozi, A. "A Study of Destructive Destructions of Foundations and Methods for Prevention of Failures and Introduction of their Revitalization and Improvement Methods", Proceedings of International Conference on Human, Architecture, Civil and Urban Planning, Tehran, Iran, (2015).

[15] Alipour N. And Mahdipour, F. "Building Design Considering Proper Materials in a Hot and Humid Climate," Proceedings of the International Conference on Civil, Architecture and Urban Infrastructure, Tehran, Iran, (2015).

[16] Madi, h and Sarraf Shams, p, KaramiNejad, M. "Concrete Conversion to Thermal Reducing Concrete for Use in Hot and Humid Regions", Proceedings of the First National Conference on New and Clean Energy Management, Tehran, Iran. (2014).

[17] Sayadzadeh, M. Sadeghi, H. Shiravi, A. And Sadeghi, A. "Zero Energy Buildings from the Point of View of Cooling and Heating Installations", Proceedings of the First National Conference on Building and Urban Energy, Tehran, Iran, (2015).

[18] Jalili, T. Zareian, R and Shahruyi Sh, "Reducing heat transfer to the building in order to prevent energy losses in the warm and semi-humid climate", Proceedings of the National Conference on Contemporary Challenges in Architecture, Landscape and Urban Planning, Tehran, Iran, (2016). 